\title{
W SPRAWIE ZASKARŻALNOŚCI STUDIUM UWARUNKOWAŃ I KIERUNKÓW ZAGOSPODAROWANIA PRZESTRZENNEGO GMINY
}

\section{ABOUT THE SUITABILITY OF THE STUDY OF THE MUNICIPALITY LAND USE CONDITIONS AND DIRECTIONS}

\section{STRESZCZENIE}

Obowiązkiem każdej gminy jest opracowanie i uchwalenie stadium uwarunkowań i kierunków zagospodarowania przestrzennego. Jego istnienie jest niezbędną przesłanką sporządzenia i uchwalenie miejscowego planu zagospodarowania przestrzennego, który musi być zgodny z takim studium. To ostatnie bezspornie dotyczy spraw z zakresu administracji publicznej, a w konsekwencji może zostać poddane kontroli sądu administracyjnego. Prawo skargi sądowoadministra-

* Prof. dr hab., kierownik Katedry Prawa Górniczego i Ochrony Środowiska, Wydział Prawa i Administracji Uniwersytetu Śląskiego. 
cyjnej przysługuje właścicielowi objętej takim studium nieruchomości gruntowej.

\section{Słowa kluczowe}

Gmina, planowanie przestrzenne, studium uwarunkowań i kierunków zagospodarowania przestrzennego, kontrola sądu administracyjnego, legitymacja skargowa.

\section{ABSTRACT}

Every local municipality must draft and its council enact the study of the land use conditions and directions, what is considered as the first step for the drafting and enacting of the local development plan. What more, the above stadium is binding for the future local development plan. The last one is the general binding local law and may be controlled by the administrative court. However the stadium must not be considered as the local law, it has the form of the resolution of the local municipality council referring to the public administration. In consequence the above study (however indirectly) may determine the legal position of the landowner, what gives him the right to sue the study to the administrative court.

Keywords

Local municipality, local development plan, study of land use conditions and directions, administrative courts, the right to sue.

Stosownie do art. 3 ust. 1 ustawy z dnia 27 marca 2003 r. o planowaniu i zagospodarowaniu przestrzennym ${ }^{1}$ kształtowanie i prowadzenie polityki przestrzennej na terenie gminy, w tym uchwalanie studium uwarunkowań i kierunków zagospodarowania przestrzennego oraz miejscowych planów zagospodarowania przestrzennego, należy do zadań własnych gminy. Inaczej mówiąc, gmina musi je realizować, w dodatku na własny koszt i na własną odpowiedzialność. Co więcej, korzysta

1 Dz.U. 2012, poz. 647 ze zm. (dalej cyt. jako „u.p.z.p.”). 
ona ze znacznej swobody w zakresie ustalania treści wspomnianych rozwiązań ${ }^{2}$. Politykę przestrzenną gminy, w tym lokalne zasady zagospodarowania przestrzennego określa tzw. studium uwarunkowań i kierunków zagospodarowania przestrzennego $^{3}$ (art. 10 u.p.z.p.). Sporządza się je dla całego obszaru każdej gminy ${ }^{4}$. Procedura jego sporządzania jest zbliżona do tej, w której powstają miejscowe plany zagospodarowania przestrzennego ${ }^{5}$. Dość wspomnieć, że studium powstaje z udziałem społeczeństwa, a nadto z zachowaniem wymagań dotyczących strategicznej oceny oddziaływania na środowisko6. Szczegóły wypada pominąć.

Treść studium jest determinowana zarówno wymaganiami przewidzianymi cytowaną ustawą z dnia 27 marca 2003 r., jak i wieloma przepisami szczegółowymi. Co prawda sporządzenie go jest tzw. zadaniem własnym gminy, to jednak musi ono „uwzględniać” zasady określone w koncepcji przestrzennego zagospodarowania kraju, ustalenia strategii rozwoju i planu zagospodarowania przestrzennego województwa oraz (o ile została uchwalona) strategii rozwoju gminy (art. 9 u.p.z.p.). Niezależnie od tego studium winno uwzględniać oraz określać uwarunkowania wynikające w szczególności z:

1) dotychczasowego przeznaczenia, zagospodarowania i uzbrojenia terenu,

2) stanu ładu przestrzennego i wymagań jego ochrony,

3) stanu środowiska, w tym stanu rolniczej i leśnej przestrzeni produkcyjnej, wielkości i jakości zasobów wod-

2 Zob. art. 7 ust. 1 pkt 1 ustawy z dnia 8 marca 1990 r. o samorządzie gminnym, Dz.U. 2001 r. Nr 1421591 (dalej cyt. jako „u.s.g.”). Za sprawą licznych przepisów odrębnych sfera wspomnianej samodzielności planistycznej gminy nieustannie się kurczy.

3 Dalej powoływane jako „studium”.

4 Zob. K. Świderski, Uwagi na temat prawnych instrumentów kształtowania ładu przestrzennego przez gminę, „Casus” 2006, nr 3, s. 22 i nast.

5 Dalej powoływanych jako „plany miejscowe”.

6 Zob. art. 46 pkt 1 ustawy z dnia 3 października 2008 r. o udostępnianiu informacji o środowisku i jego ochronie, udziale społeczeństwa w ochronie środowiska oraz o ocenach oddziaływania na środowisko, Dz.U. Nr 199, poz. 1227 ze zm. 
nych oraz wymagań ochrony środowiska, przyrody i krajobrazu kulturowego,

4) stanu dziedzictwa kulturowego i zabytków oraz dóbr kultury współczesnej,

5) warunków i jakości życia mieszkańców, w tym ochrony ich zdrowia,

6) zagrożenia bezpieczeństwa ludności i jej mienia,

7) potrzeb i możliwości rozwoju gminy,

8) stanu prawnego gruntów,

9) występowania obiektów i terenów chronionych na podstawie przepisów odrębnych,

10) występowania obszarów naturalnych zagrożeń geologicznych ${ }^{7}$,

11) występowania udokumentowanych złóż kopalin oraz zasobów wód podziemnych,

12) występowania terenów górniczych wyznaczonych na podstawie przepisów odrębnych,

13) stanu systemów komunikacji i infrastruktury technicznej, w tym stopnia uporządkowania gospodarki wodno-ściekowej, energetycznej oraz gospodarki odpada$\mathrm{mi}$,

14) zadań służących realizacji ponadlokalnych celów publicznych,

15) wymagań dotyczących ochrony przeciwpowodziowej,

16) kierunki zmian w strukturze przestrzennej gminy oraz w przeznaczeniu terenów,

17) kierunki i wskaźniki dotyczące zagospodarowania oraz użytkowania terenów, w tym tereny wyłączone z zabudowy,

18) obszary oraz zasady ochrony środowiska i jego zasobów, ochrony przyrody, krajobrazu kulturowego i uzdrowisk,

19) obszary i zasady ochrony dziedzictwa kulturowego i zabytków oraz dóbr kultury współczesnej,

20) kierunki rozwoju systemów komunikacji i infrastruktury technicznej,

2/2013 $\quad 7$ Zwłaszcza zagrożonych ruchami masowymi ziemi. 
21) obszary, na których rozmieszczone będą inwestycje celu publicznego o znaczeniu lokalnym,

22) obszary, na których rozmieszczone będą inwestycje celu publicznego o znaczeniu ponadlokalnym, zgodnie $\mathrm{z}$ ustaleniami planu zagospodarowania przestrzennego województwa i ustaleniami programów, o których mowa w art. 48 ust. 1 (tj. zawierających zadania rządowe służące realizacji inwestycji celu publicznego o znaczeniu krajowym),

23) obszary, dla których obowiązkowe jest sporządzenie miejscowego planu zagospodarowania przestrzennego na podstawie przepisów odrębnych, w tym obszary wymagające przeprowadzenia scaleń i podziału nieruchomości oraz obszary przestrzeni publicznej,

24) obszary, dla których gmina zamierza sporządzić miejscowy plan zagospodarowania przestrzennego, $\mathrm{w}$ tym obszary wymagające zmiany przeznaczenia gruntów rolnych i leśnych na cele nierolnicze i nieleśne,

25) kierunki i zasady kształtowania rolniczej i leśnej przestrzeni produkcyjnej,

26) obszary szczególnego zagrożenia powodzią̧ oraz obszary osuwania się mas ziemnych,

27) obiekty lub obszary, dla których wyznacza się w złożu kopaliny filar ochronny ${ }^{9}$

28) obszary pomników zagłady i ich stref ochronnych oraz obowiązujące na nich ograniczenia prowadzenia działalności gospodarczej, zgodnie z przepisami ustawy z dnia 7 maja 1999 r. o ochronie terenów byłych hitlerowskich obozów zagłady ${ }^{10}$,

29) obszary wymagające przekształceń, rehabilitacji lub rekultywacji,

8 Zob. art. 9 ust. 1 pkt 6c ustawy z dnia 18 lipca 2001 r. - Prawo wodne, Dz.U. 2012, poz. 145 ze zm.

9 Zob. art. 104 ustawy z dnia 9 czerwca 2011 r. - Prawo geologiczne i górnicze, Dz.U. Nr 163, poz. 981 ze zm.

10 Dz.U. Nr 41, poz. 412, ze zm. 
30) granice terenów zamkniętych ${ }^{11}$ i ich stref ochronnych,

31) inne obszary problemowe, w zależności od uwarunkowań i potrzeb zagospodarowania występujących w gminie.

Dalsze szczegóły określa zarówno cyt. ustawa z dnia 27marca 2003 r., jak również przepisy szczegółowe, zwłaszcza odnoszące się do:

1) ochrony środowiska ${ }^{12}$,

2) ochrony przyrody ${ }^{13}$,

3) geologii i górnictwa,

4) gospodarki wodnej,

5) zbiorowego zaopatrywania w wodę i odprowadzania ścieków ${ }^{14}$,

6) ewidencji gruntów.

Nie powinno też być wątpliwości co do tego, że studium musi respektować te rozstrzygnięcia podejmowane na szczeblu ponadgminnym, które określają przeznaczenie terenu w oderwaniu od systemu planowania i zagospodarowania przestrzennego ${ }^{15}$.

W uproszczeniu można przyjąć, że treścią studium jest usystematyzowana ewidencja dotychczasowego stanu zagospodarowania gminy (w tym jej środowiska) oraz polityka zamierzonych jej zmian, wielokrotnie determinowanych rozstrzygnięciami podejmowanymi przez inne organy administracji publicznej. Studium uchwala rada gminy. Pomijając ocenę celo-

11 Zob. art. 2 pkt 9 ustawy z dnia 17 maja 1989 r. Prawo geodezyjne i kartograficzne, Dz.U. 2010 Nr 193, poz. 1287 ze zm.

12 Zob. np. ustawę z dnia 27 kwietnia 2001 r. - Prawo ochrony środowiska, Dz.U. 2008 Nr 25, poz. 150 ze zm. (dalej cyt. jako „pr.o.ś.”).

13 Zob. zwł. ustawę z dnia 16 kwietnia 2004 r. o ochronie przyrody, Dz.U. $2009 \mathrm{Nr}$ 151, poz. 1120 ze zm.

14 Zob. ustawę z dnia 7 czerwca 2001 r., Dz.U. 2006 Nr 123, poz. 858 ze zm.

15 Jak np. stanowiących konsekwencje decyzji podejmowanych chociażby na podstawie ustawy z dnia 10 kwietnia 2003 r. o szczególnych zasadach przygotowania i realizacji inwestycji w zakresie dróg publicznych (Dz.U. 2008 Nr 193, poz. 1194 ze zm.) czy też ustawy z dnia 12 lutego 2009 r. o szczególnych zasadach przygotowania i realizacji inwestycji w zakresie lotnisk użytku publicznego (Dz.U. Nr 42, poz. 340 ze zm.). 
wości istnienia tego dokumentu, wypada zwrócić uwagę, że nie jest ono wprawdzie aktem prawa miejscowego, niemniej jednak jest wiążące przy sporządzaniu miejscowego planu zagospodarowania przestrzennego. Niezbędną przesłanką uchwalenia tego ostatniego jest bowiem stwierdzenie zgodności jego projektu ze studium (art. 9 ust. 4, art. 20 ust. 1 u.p.z.p.). Oznacza to jednocześnie, że treść studium determinuje treść przyszłego planu miejscowego. Omówienie związanych z tym szczegółów znowu wykracza poza ramy tematu.

Skoro studium nie ma charakteru normatywnego (nie jest aktem prawa miejscowego, art. 9 ust. 5 u.p.z.p.), to w konsekwencji nie może być powoływane jako podstawa decyzji administracyjnych oraz innych rozstrzygnięć ${ }^{16}$. Jeżeli dla danego terenu nie sporządzono planu miejscowego, zasadą jest, że o przeznaczeniu (dozwolonym sposobie wykorzystania) nieruchomości przesądza decyzja w sprawie warunków zabudowy i zagospodarowania terenu (art. 4 ust. 2 u.p.z.p.). Ta ostatnia nie może natomiast naruszać „przepisów odrębnych”"17 (zob. rt. 56 oraz art. 61 u.p.z.p.). Niekiedy może jednak być inaczej. Tak więc stosownie do art. 7 pr.g.g. podejmowanie działalności regulowanej tym prawem dozwolone jest tylko wówczas, jeżeli nie naruszy ona przeznaczenia nieruchomości określonego $\mathrm{w}$ planie miejscowym oraz $\mathrm{w}$ odrębnych przepisach (ust. 1). W razie braku planu miejscowego planu jest ono dopuszczalne tylko wówczas, jeżeli nie naruszy sposobu wykorzystywania nieruchomości ustalonego w studium uwarunkowań i kierunków zagospodarowania przestrzennego gminy oraz w odrębnych przepisach (ust. 2). Co prawda to ostatnie rozwiązanie stanowi swego rodzaju kuriozum jaskrawo kolidujące z podstawowymi konstrukcjami wspomnianej ustawy z dnia 27 marca 2003 r., to jednak nie można negować jego istnienia. Praktyczna strona

16 Chyba że przepis szczególny stanowi inaczej.

17 Co w istocie jest skrótem myślowym. Chodzi tu nie tylko o sytuacje, w których przeznaczenie terenu bezpośrednio jest determinowane innymi aktami normatywnymi (jnp. dotyczącymi ochrony gruntów rolnych i leśnych), ale również rozstrzygnięciami podejmowanymi na podstawie aktów normatywnych innych niż u.p.z.p. 
funkcjonowania art. 7 pr.g.g. polega na tym, że przede wszystkim wyznacza on m.in. przesłanki, jakimi winny kierować się organy współdziałające przy podejmowaniu niektórych decyzji dotyczących geologii i górnictwa, czego przykładem może być uzgodnienie koncesji na wydobywanie kopalin dokonywane przez organ wykonawczy gminy).

Powstaje pytanie, jakie mają być sankcje z tytułu braku studium. Artykuły 9 i 12 u.p.z.p. zredagowane są w formie imperatywnej. Rada gminy musi zatem uchwalić studium obejmujące całe terytorium gminy. Jeżeli nie zostanie ono uchwalone, nie można uchwalić planu miejscowego; ten ostatni musi bowiem być zgodny ze studium. Zgodzić się też należy z oceną, że uchylenie się przez radę gminy od sporządzenia i uchwalenia studium oznacza jej bezczynność i uzasadnia skargę opartą na art. 101a u.s.g. ${ }^{18}$ Jeżeli natomiast rada gminy nie uchwaliła studium, nie przystąpiła do jego zmiany albo, uchwalając studium, nie określiła $\mathrm{w}$ nim obszarów rozmieszczenia inwestycji celu publicznego o znaczeniu krajowym i wojewódzkim, ujętych w planie zagospodarowania przestrzennego województwa lub w tzw. programach rządowych ${ }^{19}$, wówczas wojewoda, po podjęciu czynności zmierzających do uzgodnienia terminu realizacji tych inwestycji i warunków wprowadzenia tych inwestycji do studium, wzywa radę gminy do uchwalenia studium lub jego zmiany w wyznaczonym terminie. Po bezskutecznym upływie tego terminu wojewoda sporządza miejscowy plan zagospodarowania przestrzennego albo jego zmianę dla obszaru objętego zaniechaniem gminy, w zakresie koniecznym dla możliwości realizacji inwestycji celu publicznego, co następuje w drodze zarządzenia zastępczego. Przyjęty w tym trybie plan wywołuje skutki prawne, takie jak miejscowy plan zagospodarowania przestrzennego uchwalony przez radę gminy (art. 15). Zbliżone rozwiązanie przewiduje art. 96 pr.g.g. Jeżeli w terminie 2 lat od zatwierdzenia dokumentacji geologicznej złoża

18 K.Świderski, Uwagi na temat..., s. 22 i nast.

19 O których mowa w art. 48 ust. 1 u.p.z.p. Problem ten ma jednak walor czysto teoretyczny, gdyż dotychczas nie doszło do sformułowania takich programów. 
kopaliny objęty nią obszar nie zostanie ujawniony w studium (art. 72 pr.o.ś., art. 95-96 pr.g.g.), kompetencje do zmiany tego ostatniego przejmuje wojewoda, który w drodze zarządzenia zastępczego wprowadza taką informację do studium, a koszt ponosi gmina.

Przedstawione wyżej uwagi w pełni uzasadniają ocenę, że studium musi zawierać ściśle określone treści stanowiące konsekwencję nie tylko uwarunkowań stanu środowiska terytorium gminy, ale również polityki zmian sposobu jego zagospodarowania. Poza sporem pozostaje, że znaczna część elementów środowiska objęta jest prawami przysługującymi różnym podmiotom, przede wszystkim zaś właścicielom nieruchomości. Mogą oni być żywotnie zainteresowani ukształtowaniem studium w sposób zgodny z wymaganiami prawa oraz własnymi oczekiwaniami dotyczącymi przyszłej, następującej w zasadzie dopiero w planie miejscowym, zmianie przeznaczenia nieruchomości. Przykładem może być chociażby zmiana przeznaczenia gruntu rolnego (leśnego) na inne cele. Przypomnieć wypada, że plan miejscowy musi być zgodny ze studium. Za sprawą wspomnianego wyżej art. 7 pr.g.g. studium może stanowić podstawę uzgodnienia koncesji na wydobywanie kopaliny ze złoża. Powstaje zatem pytanie, czy oraz ewentualnie kto i w jakim trybie może badać zgodność studium z prawem czy też inicjować postępowanie w tej sprawie.

Studium przyjmowane jest w drodze uchwały organu stanowiącego gminy. Obowiązkiem organu wykonawczego tej ostatniej jest przedstawienie wojewodzie uchwały o uchwaleniu studium wraz z załącznikami oraz dokumentacją prac planistycznych w celu oceny ich zgodności z przepisami prawnymi (art. 12 ust. 2 u.p.z.p.). Z kolei skutkiem naruszenia zasad sporządzania studium, istotnego naruszenia trybu ich sporządzania, a także naruszenia właściwości organów w tym zakresie, jest nieważność (całości bądź części) uchwały rady gminy, co stwierdza wojewoda w drodze tzw. rozstrzygnięcia nadzorczego. To ostatnie podlega kontroli sądowoadministracyjnej, tyle że inicjowanej w zasadzie wyłącznie przez radę gminy. Związane z tym szczegóły określają art. 90 i nast. u.s.g. 
Należy też przyjąć, pomimo przemilczenia tego w ustawie, że uchwała $\mathrm{w}$ sprawie przyjęcia studium dotyczy spraw z zakresu administracji publicznej. Tym samym oznacza to dopuszczalność poddania jej kontroli sądowoadministracyjnej, tyle że inicjowanej w trybie art. 100 u.s.g. w zw. z art. art. $3 \S 2$ pkt 6 p.p.s.a. ${ }^{20}$ Inaczej mówiąc, ten, kto uważa, że jego interes prawny lub uprawnienie zostały naruszone uchwałą lub zarządzeniem podjętymi przez organ gminy w sprawie z zakresu administracji publicznej, może - po bezskutecznym wezwaniu do usunięcia naruszenia - zaskarżyć uchwałę do sądu administracyjnego (chyba że taka uchwała była już przedmiotem kontroli sądowoadministracyjnej). Ocena ta znajduje swe potwierdzenie $\mathrm{w}$ orzecznictwie sądowoadministracyjnym ${ }^{21}$. Pomimo że studium nie stanowi przepisów powszechnie obowiązujących i jest aktem kierownictwa wewnętrznego, to jednak - skoro ustalenia studium są wiążące przy sporządzaniu planów miejscowych, może ona doprowadzić do naruszenia interesu prawnego poszczególnych podmiotów. Ustalenia studium wiążą bowiem organy gminy przy sporządzaniu planów miejscowych, co wynika z art. 9 ust. 4, art. 20 ust. 1 u.p.z.p. ${ }^{22}$

Trafnie też sądy administracyjne przyjmują, że studium, jako że nie jest aktem prawa miejscowego, to nie może wprowadzać ograniczeń godzących $\mathrm{w}$ interesy prawne podmiotów, a w szczególności wpływać bezpośrednio na sposób wykonywania prawa własności nieruchomości gruntowych znajdujących się na objętym nim obszarze. Na takie ukształtowanie studium nie zezwala bowiem żaden przepis prawa (zob. art. 7 Konstytucji). Swego rodzaju wyjątkiem jest natomiast art. 7 pr.g.g.

20 Ustawa z dnia z dnia 30 sierpnia 2002 r. - Prawo o postępowaniu przed sądami administracyjnymi, Dz.U. 2012, poz. 270 ze zm.

21 Tak trafnie NSA w wyroku z dnia 26 lutego 2008 r., II OSK 1765/07.

22 Zob. np. wyroki NSA:

- z dnia 7 grudnia 2006 r., II OSK 839/06,

- z dnia 3 sierpnia 2007 r. II OSK 614/07,

- z dnia 22 listopada 2007 r. II OSK 1337/07,

- z dnia 8 kwietnia 2010r. II OSK 123/10,

- z dnia 22 marca 2012 r. II OSK 22/12. 
Nie można natomiast wykluczyć, że rada gminy uchwalając studium, wprowadzi rozwiązania naruszające interes właściciela nieruchomości. Przykładem może być sytuacja, w której studium wprowadziło ograniczenia dotyczące wydobywania znajdujących się na objętej nim nieruchomości złoża kopaliny (piasku) w sposób powodujący, że koncesji na jego wydobywanie mógł udzielić wyłącznie starosta ${ }^{23}$. Wielkość tego złoża pozwalała natomiast na objęcie go koncesją na wydobywanie wydaną przez marszałka województwa ${ }^{24}$. W konsekwencji uzasadniony może być zarzut naruszenia wypowiedzianej $\mathrm{w}$ art. 125 pr.o.ś. zasady racjonalnego wykorzystania zasobów złoża kopaliny. Gwoli ścisłości należy dodać, że art. 22 ust. 3 pr.g.g. przewiduje, że przedsiębiorca, który otrzymał od starosty koncesję na wydobywanie kopaliny ze złoża przylegającego do złoża już objętego koncesją udzieloną temu samemu przedsiębiorcy na ten sam rodzaj działalności, może rozpocząć wydobywanie kopaliny nie wcześniej niż w dniu, w którym decyzja stwierdzająca wygaśnięcie koncesji wcześniejszej stanie się ostateczna. Inaczej mówiąc, ustawa ogranicza dzielenie dużego złoża takiej kopaliny na kilka mniejszych w celu uzyskiwania na tak powstałe (małe) złoża kilku koncesji starosty ${ }^{25}$. W praktyce nie sposób natomiast wyobrazić sobie możliwości funkcjonowania takiego rozwiązania z poszanowaniem zasady wypowiedzianej w art. 125 pr.o.ś.

Warto też odnotować, że praktyka odnotowuje sytuacje, w których treścią studium bywają ograniczenia odnoszące się

23 Stosownie do art. 22 ust. 2 pr.g.g. starosta koncesjonuje wydobywanie kopalin, jeżeli jednocześnie spełnione są następujące przesłanki:

1) obszar udokumentowanego złoża nieobjętego własnością górniczą nie przekracza 2 ha,

2) ydobycie kopaliny ze złoża w roku kalendarzowym nie przekroczy $20000 \mathrm{~m}^{3}$,

3) działalność będzie prowadzona metodą odkrywkową oraz bez użycia środków strzałowych.

24 Czyli bez ograniczeń wynikających z art. 22 ust. 2 pr.g.g.

25 Wydobywanie kopalin na podstawie koncesji starosty odbywa się na uproszczonych zasadach, z wyłączeniem niektórych rygorów prawa geologicznego i górniczego. 
do projektowanej kopalni, nakładające na właściciela nieruchomości obowiązki oraz ograniczenia, jak np. przekazywania raportów z głębokości wyrobiska czy też nakazujące uzgodnienie drogi transportu wydobytej kopaliny, co zarówno:

1) ewidentnie kształtuje sposób wykonywania prawa własności nieruchomości, a w dodatku

2) wkracza w kompetencje innych organów (administracji geologicznej, sprawujących zarząd dróg publicznych) ${ }^{26}$.

Co prawda ograniczenia prawa właściciela nieruchomości w zakresie wydobywania objętych nią złóż kopalin mogą znaleźć swe podstawy w miejscowym planie zagospodarowania przestrzennego (którego podstawową funkcją jest określenie przeznaczenia objętych nim nieruchomości), tyle że brak dostatecznych podstaw prawnych (zob. art. 7 Konstytucji), by wprowadzać je w drodze studium. Prawo własności może zostać ograniczone wyłącznie w drodze ustawy (art. 64 ust. 3 Konstytucji), czego nie można jednak rozumieć dosłownie. Podstawą takich ograniczeń mogą być również działania polegające na stosowaniu prawa, tyle że wyłącznie wówczas, gdy mają podstawy ustawowe (zob. np. art. 4 ust. 1 u.p.z.p.) i tylko wówczas, gdy nie naruszają one istoty prawa własności. Zgodnie natomiast $\mathrm{z}$ wypowiedzianą $\mathrm{w}$ art. 31 ust. 3 Konstytucji zasadą proporcjonalności ograniczenia w zakresie korzystania z konstytucyjnych wolności i praw mogą być ustanawiane tylko w ustawie i tylko wtedy, gdy są konieczne w demokratycznym państwie dla jego bezpieczeństwa lub porządku publicznego, bądź dla ochrony środowiska, zdrowia i moralności publicznej, albo wolności i praw innych osób. Brak miejsca nie zezwala na rozwinięcie tego tematu.

W literaturze przedmiotu pojawił się natomiast pogląd, że „żaden podmiot nie będzie miał interesu prawnego przy okazji kwestionowania w formie skargi uchwały dotyczącej przyjęcia studium [...] - nawet przy okazji kwestionowania tylko bra-

26 Zob. wyrok WSA z dnia 23 lipca 2012 r., II S.A./Gl 243/12 (nieprawomocny). 
ków formalnych w procesie przygotowania studium. Formuła studium przesądza bowiem o tym, że nie wywołuje ono bezpośrednich skutków prawnych - również dla użytkowników przestrzeni" ${ }^{27}$. Jako element uzasadnienia tej oceny autorzy powołują wyrok WSA z dnia 8 grudnia 2010 r. (II S.A./Kr 713/10) ${ }^{28}$. Ocena ta nie znajduje jednak dostatecznych podstaw prawnych. Przede wszystkim:

- studium determinuje treść przyszłego planu miejscowego, który musi (pod rygorem nieważności) być zgodny ze studium,

- teza zakładająca, że właściciel nieruchomości nie ma interesu prawnego $\mathrm{w}$ ukształtowaniu treści studium w sposób zgodny z wymaganiami prawa musi zostać oceniona jako kolidująca z konstytucyjnymi gwarancjami prawa własności,

- za sprawą art. 7 pr.g.g. treść studium może wpływać na podjęcie decyzji zezwalających na wykonywanie działalności regulowanej prawem geologicznym i górniczym (przede wszystkim zaś podlegającej koncesjonowaniu, art. 21 pr.g.g.),

- legitymacja do złożenia skargi sądowoadministracyjnej nie zależy od tego, czy dany akt bezpośrednio wpływa na interes prawny danego podmiotu, czego przykładem może być chociażby legitymacja skargowa prokuratora bądź Rzecznika Praw Obywatelskich (art. 8 § 1 p.p.s.a.),

- powołany wyżej wyrok WSA z dnia 8 grudnia 2010 r. zawierający ocenę, jakoby skarga sądowoadministracyjna stanowiąca środek prawnej ochrony ma mieć charakter potencjalny („którego wykluczyć nie można, ale który będzie mógł odnieść skutek wyjątkowo. Co do zasady

27 M.J. Nowak, Z. Olech, Zaskarżalność studium uwarunkowań i kierunków zagospodarowania przestrzennego do sadu administracyjnego, „Radca Prawny. Dodatek naukowy", nr 135, marzec 2013, s. 16 i nast., zwł. s. 18. Zob. również T. Bąkowski, Ustawa o planowaniu i zagospodarowaniu przestrzennym. Komentarz, Zakamycze 2004 (wersja elektroniczna); Z. Niewiadomski, Ustawa o planowaniu przestrzennym. Komentarz, Warszawa 2004, s. 88.

28 Lex 753600. 
skarżący nie zdoła wykazać, że studium narusza jego interes prawny lub uprawnienie"), został uchylony ${ }^{29}$.

Co prawda można zgodzić się z oceną, że studium przeważnie nie powoduje bezpośrednich skutków prawnych w sferze uprawnień właściciela, to jednak nie sposób aprobować tezy, że skutki o charakterze „pośrednim” dla właściciela wykluczają interes prawny tego ostatniego. Trafnie też NSA przyjmuje, że studium nie mając charakteru aktu prawa miejscowego, „nie kształtuje sposobu korzystania z własności, ale wiążąc radę gminy, pośrednio może wpływać na interes prawny właścicieli nieruchomości objętych postanowieniami studium"30. W konsekwencji ocena, jakoby właściciel nieruchomości mógłby zostać pozbawiony prawa zainicjowania postępowania zmierzającego do wyeliminowania rozwiązań studium naruszających prawo wymaga odrzucenia. Odmienna konkluzja ewidentnie koliduje z istotą prawa własności i jego konstytucyjnymi gwarancjami.

Nie sposób też pominąć praktyczne konsekwencje sądowoadministracyjnej kontroli wspomnianych studiów, zwłaszcza inicjowanej przez właścicieli (użytkowników wieczystych) nieruchomości. Analiza orzecznictwa sądowoadministracyjnego dostarcza bowiem licznych przykładów świadczących o tym, że wspomniane studia powstają z istotnym naruszeniem prawa. Wykazanie tej okoliczności przed sporządzeniem i uchwaleniem planu miejscowego może wykluczyć przeniesienie błędnych rozwiązań studium do tego ostatniego.

\section{BIBLIOGRAFIA}

Świderski K., Uwagi na temat prawnych instrumentów kształtowania ładu przestrzennego przez gminę, „Casus” 2006 nr 3.

29 Co nastąpiło wyrokiem NSA z dnia 6 lipca 2011 r., II OSK 839/11.

30 Tak w zasadzie trafnie NSA w wyroku z dnia 22 marca 2012 r., II OSK 22/12. Skład orzekający nie dostrzegł natomiast, ze za sprawą art. 7 ust. 2 pr.g.g. studium może bezpośrednio wpływać na treść prawa własności nieruchomości gruntowej. 
Nowak M. J., Olech Z., Zaskarżalność studium uwarunkowań i kierunków zagospodarowania przestrzennego do sądu administracyjnego, „Radca Prawny. Dodatek naukowy. Numer” 135, marzec 2013.

Bąkowski T., Ustawa o planowaniu i zagospodarowaniu przestrzennym. Komentarz, Zakamycze 2004 (wersja elektroniczna).

Niewiadomski Z., Ustawa o planowaniu przestrzennym. Komentarz, Warszawa 2004.

Kontakt e-mail:

aleksander.lipinski@us.edu.pl 